\section{Literature Abstracts}

\author{
Ma D, Li Y, Hackfort B, Zhao Y, Xiao J, Swanson \\ PC, Lappe J, Xiao P, Cullen D, Akhter M, Recker R, \\ Xiao GG. Smoke-induced signal molecules in bone \\ marrow cells from altered low-density lipoprotein \\ receptor-related protein 5 mice. J Proteome \\ Res. 2012 Jul 6;11(7):3548-60. Epub 2012 Jun 4. \\ [Medline: 22616666] [doi: 10.1021/pr2012158]
}

Mechanism underlying smoke-induced loss of bone mass is unknown. In this study, authors hypothesized that protein signals induced by smoking in bone marrow may be associated with the loss of bone mass.

Using a proteomics approach, they identified 38 proteins differentially expressed in bone marrow cells from low-density lipoprotein receptor-related protein 5 (Lrp5) mice exposed to cigarette smoking. Smoking effects on protein expression in bone marrow among three genotypes (Lrp5(+/+), Lrp5(G171V), and Lrp5(-/)) varied. On the basis of the ratio of protein expression induced by smoking versus nonsmoking, smoke induced protein expression significantly in wild-type mice compared to the other two genotypes (Lrp5(G171V) and $\operatorname{Lrp5}(-/-))$. These proteins include inhibitors of $\beta$-catenin and proteins associated with differentiation of osteoclasts. Authors observed that S100A8 and S100A9 were overexpressed in human smokers compared to nonsmokers, which confirmed the effect of smoking on the expression of two proteins in Lrp5 mice, suggesting the role of these proteins in bone remodelling. Smoke induced expression of S100A8 and S100A9 in a timedependent fashion, which was opposite of the changes in the ratio of OPG/RANKL in bone marrow cells, suggesting that the high levels of S100A8 and S100A9 may be associated with smoke-induced bone loss by increasing bone resorption.

Gao SG, Cheng L, Li KH, Liu WH, Xu M, Jiang W, Wei LC, Zhang FJ, Xiao WF, Xiong YL, Tian J, Zeng C, Sun JP, Xie Q, Lei GH. Effect of epimedium pubescen flavonoid on bone mineral status and bone turnover in male rats chronically exposed to cigarette smoke. BMC Musculoskelet Disord. 2012 Jun 19;13:105. [Medline: 22713117] [PMC free article: 3480917] [doi: 10.1186/1471-247413-105]

BACKGROUND: Epimedii herba is one of the most frequently used herbs in formulas that are prescribed for the treatment of osteoporosis in China and its main constituent is Epimedium pubescen flavonoid (EPF). However, it is unclear whether EPF during chronic exposure to cigarette smoke may have a protective influence on the skeleton. The present study investigated the effect of EPF on bone mineral status and bone turnover in a rat model of human relatively high exposure to cigarette smoke.

METHODS: Fifty male Wistar rats were randomized into five groups: controls, passive smoking groups and passive smoking rats administered EPF at three dosage levels $(75,150$ or $300 \mathrm{mg} / \mathrm{kg} /$ day) in drinking water for 4 months. A rat model of passive smoking was prepared by breeding male rats in a cigarette-smoking box. Bone mineral content (BMC), bone mineral density (BMD), bone turnover markers, bone histomorphometric parameters and biomechanical properties were examined.

RESULTS: Smoke exposure decreased BMC and BMD, increased bone turnover (inhibited bone formation and stimulated its resorption), affected bone histomorphometry (increased trabecular separation and osteoclast surface per bone surface; decreased trabecular bone volume, trabecular thickness, trabecular number, cortical thickness, bone formation rate and osteoblast surface per bone surface), and reduced mechanical properties. EPF supplementation during cigarette smoke exposure prevented smoke-induced changes in bone mineral status and bone turnover.

CONCLUSION: Authors conluded that the results suggest that EPF can prevent the adverse effects of smoke exposure on bone by stimulating bone formation and inhibiting bone turnover and bone resorption.

Iqbal J, Sun L, Cao J, Yuen T, Lu P, Bab I, Leu NA, Srinivasan S, Wagage S, Hunter CA, Nebert DW, Zaidi M, Avadhani NG. Smoke carcinogens cause bone loss through the aryl hydrocarbon receptor and induction of Cyp1 enzymes. Proc Natl Acad Sci U S A. 2013 Jul 2;110(27):11115-20. Epub 2013 Jun 17. [Medline: 23776235] [PMC free article: 3704019] [doi: 10.1073/pnas.1220919110]

Smoking is a major risk factor for osteoporosis and fracture, but the mechanism through which smoke causes bone loss remains unclear.

Here, authors show that the smoke toxins benzo(a)pyrene (BaP) and 2,3,7,8-tetrachlorodibenzo-p-dioxin (TCDD) interact with the arylhydrocarbon receptor (Ahr) to induce osteoclastic bone resorption through the activation of cytochrome P450 1a/1b (Cyp1) enzymes. BaP and TCDD enhanced osteoclast formation in bone marrow cell cultures and gavage with $\mathrm{BaP}$ stimulated bone 
resorption and osteoclastogenesis in vivo. The osteoclastogenesis triggered by $\mathrm{BaP}$ or RANK-L was reduced in $\mathrm{Ahr}(-/-)$ cells, consistent with the highbone mass noted in $\mathrm{Ahr}(-/-)$ male mice. The receptor activator of $\mathrm{NF}-\kappa \mathrm{B}$ ligand (RANK-L) also failed to induce the expression of Cyplenzymes in Ahr(-/-) cells. Furthermore, the osteoclastogenesis induced by TCDD was lower in Cyp1a1/1a2(-/-) and Cyp1a1/1a2/1b1(-/-) cultures, indicating that Ahr was upstream of the Cyp enzymes. Likewise, the pharmacological inhibition of the Cyp1 enzymes with tetramethylsilane or proadifen reduced osteoclastogenesis. Finally, deletion of the Cyp1a1, Cyp1a2, and Cyp1b1 in triple knockout mice resulted in reduced bone resorption and recapitulated the high bone mass phenotype of Ahr(-/-) mice.

Overall, the data identify the Ahr and Cyp1 enzymes not only in the pathophysiology of smoke-induced osteoporosis, but also as potential targets for selective modulation by new therapeutics.

Tanaka H, Tanabe N, Kawato T, Nakai K, Kariya T, Matsumoto S, Zhao N, Motohashi M, Maeno M. Nicotine affects bone resorption and suppresses the expression of cathepsin K, MMP-9 and vacuolartype $H(+)$-ATPase $d 2$ and actin organization in osteoclasts. PLoS One. 2013;8(3):e59402. Epub 2013 Mar 15. [Medline: 23555029] [PMC free article: 3598738] [doi: 10.1371/journal.pone.0059402]

Tobacco smoking is an important risk factor for the development of several cancers, osteoporosis, and inflammatory diseases such as periodontitis. Nicotine is one of the major components of tobacco. In previous study, authors showed that nicotine inhibits mineralized nodule formation by osteoblasts, and the culture medium from osteoblasts containing nicotine and lipopolysaccharide increases osteoclast differentiation. However, the direct effect of nicotine on the differentiation and function of osteoclasts is poorly understood.

Thus, they examined the direct effects of nicotine on the expression of nicotine receptors and bone resorptionrelated enzymes, mineral resorption, actin organization, and bone resorption using RAW264.7 cells and bone marrow cells as osteoclast precursors. Cells were cultured with $10(-5), 10(-4)$, or $10(-3) \mathrm{M}$ nicotine and/ or $50 \mu \mathrm{M} \alpha$-bungarotoxin (btx), an 7 nicotine receptor antagonist, in differentiation medium containing the soluble RANKL for up 7 days. 1-5, 7, 9, and 10 nicotine receptors were expressed on RAW264.7 cells. The expression of 7 nicotine receptor was increased by the addition of nicotine.
Nicotine suppressed the number of tartrate-resistant acid phosphatase positive multinuclear osteoclasts with large nuclei ( $\geq 10$ nuclei), and decreased the planar area of each cell. Nicotine decreased expression of cathepsin K, MMP-9, and V-ATPase d2. Btx inhibited nicotine effects. Nicotine increased CA II expression although decreased the expression of V-ATPase $\mathrm{d} 2$ and the distribution of F-actin. Nicotine suppressed the planar area of resorption pit by osteoclasts, but did not affect mineral resorption.

These results suggest that nicotine increased the number of osteoclasts with small nuclei, but suppressed the number of osteoclasts with large nuclei. Moreover, nicotine reduced the planar area of resorption pit by suppressing the number of osteoclasts with large nuclei, V-ATPase d2, cathepsin K and MMP-9 expression and actin organization.

Fu YX, Gu JH, Zhang YR, Tong XS, Zhao HY, Yuan Y, Liu XZ, Bian JC, Liu ZP. Osteoprotegerin influences the bone resorption activity of osteoclasts. Int J Mol Med. 2013 Jun;31(6):14117. Epub 2013 Apr 4. [Medline: 23563320] [doi: $10.3892 / \mathrm{ijmm} .2013 .1329$ ]

The aim of the present study was to determine whether osteoprotegerin (OPG) influences the bone resorption activity of osteoclasts.

RAW264.7 cells were induced by macrophage colonystimulating factor (M-CSF) + receptor activator of nuclear factor- $\kappa \mathrm{B}$ ligand (RANKL) and $0,10,20,50$ and $100 \mathrm{ng} / \mathrm{ml}$ OPG were added into various groups in the presence of the two cytokines. The OPG treatment was continued for $24 \mathrm{~h}$. Osteoclast differentiation and activation were estimated via TRAP staining assay, TRITC-conjugated phalloidin staining, resorption activity analysis. Furthermore, the expression levels of the osteoclastic bone resorption-related genes MMP9, cathepsin K and carbonic anhydrase II (CA II) were examined using real-time polymerase chain reaction (PCR).

The data demonstrated that high concentrations of OPG could inhibit the differentiation and activation of osteoclasts. Furthermore, real-time PCR analysis illustrated that OPG decreased the expression of MMP9 and cathepsin $\mathrm{K}$ in different concentrations of OPG and it decreased the expression of CA II genes at 10 and $20 \mathrm{ng} / \mathrm{ml}$ concentrations of OPG. For the time gradient study, OPG decreased the expression of MMP-9 and CA II genes but not that of the cathepsin $\mathrm{K}$ gene.

In summary, the resorption activity of osteoclasts was suppressed by high concentrations of OPG and, at the molecular level, OPG decreased the expression of osteoclastic bone resorption-related genes. 
Literature Abstracts.

J Oral Maxillofac Res 2013;4(4):a1

URL: http://www.ejomr.org/JOMR/archives/2013/4/a1/v4n4a1ht.pdf

doi: $10.5037 /$ jomr.2013.44a1

Copyright $\odot$ Literature Abstracts. Published in the JOURNAL OF ORAL \& MAXILLOFACIAL RESEARCH (http://www. ejomr.org), 1 January 2014.

This is an open-access material, published in the JOURNAL OF ORAL \& MAXILLOFACIAL RESEARCH, distributed under the terms of the Creative Commons Attribution-Noncommercial-No Derivative Works 3.0 Unported License, which permits unrestricted non-commercial use, distribution, and reproduction in any medium, provided the original work and is properly cited. The copyright, license information and link to the original publication on (http://www.ejomr.org) must be included. 